\title{
The art of wasting time: sociability, friendship, community and holidays
}

\author{
Dr Carmel Foley \\ University of Technology Sydney \\ PO Box 123 \\ Broadway NSW 2007 \\ AUSTRALIA \\ Phone: 61295145102 \\ Carmel.foley@uts.edu.au
}

\section{ABSTRACT}

Slow tourism is motivated by the desire for personal and communal well-being. It emerged as an antidote to the fast-paced imperatives of global capitalism that urge the entrepreneurial self to speed up and work harder to achieve and demonstrate desired social status. The entrepreneurial self can be understood in the contexts of neoliberalism and the class and gender-based histories of time-thrift and rational recreation; the entrepreneurial self uses leisure time purposively in the pursuit of status, avoids idle pursuits, and has restricted capacity to experience leisurely social relationships. In this paper it is argued that leisurely social relations can be reclaimed by letting go, even temporarily, of time-thrift and the compulsion to use leisure time purposively. Data drawn from in-depth interviews with repeat visitors at two Australian caravan parks revealed that for the period of their holiday the tourists relax, refuse to be driven by schedules, socialise with other tourists, and feel no compulsion to use time purposively. The key reasons the tourists return to the parks each year were for the friendships and the sense of community they experience as part of the holiday. Slow tourism by its very nature rejects time-thrift, however, as the movement is harnessed by global capitalism, slow tourism risks becoming a source of conspicuous consumption. The findings of this study suggest that friendship and community thrive more readily in conditions where the need to achieve and demonstrate social status is discarded along with time-thrift. 
Foley, C. T. (2015). The art of wasting time: sociability, friendship, community and holidays. Leisure Studies. doi: $10.1080 / 02614367.2015 .1055296$

The slow movement, including slow tourism, has emerged as an "antidote to the fast paced imperatives of global capitalism that urge the entrepreneurial self to speed up, become mobile and work harder in order to be valued as successful, productive and conspicuous consumers" (Fullagar, Markwell \& Wilson, 2012, p. 1). While initially focused on environmental sustainability (Lumsden \& McGrath, 2010; Wearing, Wearing \& McDonald, 2012), we now understand that slow tourism is also motivated by the desire for improved personal and communal well-being (Oh, Assaf \& Baloglu 2014), enhanced relationships, and conviviality (Fullagar, 2012). Many have argued that the "entrepreneurial self" (Fullagar et al., 2012, p. 1) has restricted capacity in terms of ability to experience the leisurely, social relationships that underpin friendship and community (Arai \& Pedlar, 2003; McDonald, Wearing \& Ponting, 2008; Putnam, 2000; Rojek, 2005; Thompson, 1967). In this paper it will be argued that the art of friendship and sociable relations, and a sense of community can be reclaimed through the relatively straightforward techniques of letting go, even temporarily, of both time-thrift and the compulsion to use leisure time purposively. While the techniques may be fairly straightforward, the decisions to use them are profoundly contextualised in the history of class-based leisure practices and contemporary shifts in consumption and work. Data drawn from a study of two caravan park holiday communities in Australia are used to support this case.

Researchers spent four weeks at two caravan parks on the east coast of Australia conducting interviews with caravan park tourists and managers with the aim of learning more about the attractions of this type of holiday. The particular focus of the study was the experience of repeat visitors to caravan parks - tourists who return to the same caravan park for their holiday, year after year.

The tensions between convivial social relations and the entrepreneurial self are evident in following research field note which was recorded during the early days of the first caravan park visit. It documents an incident that occurred in the communal laundry of the caravan park.

Between interviews I visited the communal laundry to do some washing. There were a limited number of washing machines but after a short wait I got one and set the clothes to wash. There were timers on the machines so I had a good idea of when to return. I returned early in any case and sat on a bench in a corner to read a book that 
Foley, C. T. (2015). The art of wasting time: sociability, friendship, community and holidays. Leisure Studies. doi: $10.1080 / 02614367.2015 .1055296$

someone had left there. I was aware that there was only one dryer left free and that another washing machine was due to finish a couple of minutes before mine. I was waiting there in the hope that the owner of that load would run a bit late so that I could beat them to the last dryer. As luck would have it my load finished and I got it into the last available dryer before the woman using the competing machine entered the laundry. There were a few of us in there by then and the woman bemoaned the lack of a free dryer. I was surprised when another woman using the laundry invited my competitor to share her dryer. She opened her dryer for the extra load and the two women then went on to chat about how hard it was to get the towels dry when the kids were in and out of the water all day and the weather was a bit wet. As I listened to the conversation I realised that the women didn't really know each other they were not on holidays together, they had just seen each other around the park. I sat alone in my corner while my clothes dried (alone in their dryer), reflecting on my self-serving, calculating behaviour, the relaxed generosity of the woman who threw open her dryer, and the easy relationship that seemed to have sprung up between the two women.

The contrast in the behaviours of the occupants of the laundry underpins the discussion that follows. The self-serving, calculating behaviour of the field note author is, arguably, not an uncommon phenomenon. Indeed, tactical and competitive behaviour of this kind is expected of the "entrepreneurial self" (Fullagar et al., 2012, p. 1; McDonald et al., 2008). On the other hand, the sociable, relaxed and generous behaviour of the women who shared the dryer is, arguably, less common in contemporary western societies and worthy of further examination. The author contends that we may have something to learn about sociability from caravan park tourists.

Twenty first century commentators report a social crisis in neoliberal societies where an increase in narcissistic tendencies such as self-absorption, self-centredness and lack of empathy (McDonald et al., 2008) has produced societies populated with "self-seeking and egocentric calculators, with little social conscience or sense of mutual obligation" (Aria \& Pedlar, 2003, p. 192). This, it is argued, has contributed to a breakdown in both meaningful interpersonal relationships and the trust, friendship, reciprocity and feelings of belonging that are vital to a sense of community (Arai \& Pedlar, 2003; McDonald et al., 2008; McMillan, 1996; Putnam, 
Foley, C. T. (2015). The art of wasting time: sociability, friendship, community and holidays. Leisure Studies. doi: 10.1080/02614367.2015.1055296

2000; Rojek, 2005). The paper begins by arguing that this crisis has roots in the practice of timethrift, the creed of social advancement, and the rational recreation movement that emanated from 19th century Britain. The paper then examines the data collected from sixty seven repeat visitors to the two caravan parks which indicates that the rejection of both time-thrift and purposive leisure have allowed sociable relationships to develop and flourish in these communities. The following sections on time-thrift and rational recreation provide historical context for the contemporary attitudes and behaviours of the caravan park visitors and the slow tourism movement in general.

\section{TIME-THRIFT}

The "contemporary Western obsession with productivity, the cult of speed, and a fear of wasting time" (Ehn \& Löfgren, 2010) has a history. Centuries ago, under the influences of puritanism and industrial capitalism, the western world was encouraged to practice time-thrift: to account for time, to use time purposively, not to waste time (Thompson, 1967). It required a transition. In the mid eighteenth century the Rev. J. Clayton (1755 cited in Thompson, 1967, p. 83, emphasis in original) complained that "the Churches and streets [are] crowded with Numbers of Spectators [at weddings and funerals] who in spite of the Miseries of their Starving Condition ... make no Scruple of wasting the best Hours of the Day...”. Workers at an eighteenth century iron mill were reportedly prone to visiting "taverns, alehouses, coffee houses, ...playing, sleeping, smoking, singing, ... quarrelling...[and] loytering" during designated work hours (Thompson, 1967, p. 81). Resistance may have included the observance of St Monday well into the nineteenth century in parts of England (Walton, 2014).

Thompson (1967, p. 80) notes that the transition to time-discipline was "peculiarly contracted and fraught with conflict", in part, because "England's was the first industrial revolution and there were no Cadillacs, steel mills, or television sets to serve as demonstrations" of the rewards for the productive use of time. However, by the second half of the nineteenth century, the links between time-thrift, hard work and self-interest appear to have been made, at least by some. Robert Louis Stevenson ([c1877] 2004) complained of too many "industrious fellows" who absent themselves "from all fellowship" as they "labour themselves into great fortune". He 
Foley, C. T. (2015). The art of wasting time: sociability, friendship, community and holidays. Leisure Studies. doi: 10.1080/02614367.2015.1055296

commented on the inability of such fellows to function socially when they are not working the "gold-mill” of self-interest.

Bring these fellows into the country, or set them aboard ship, and you will see how they pine for their desk or their study. They have no curiosity; they cannot give themselves over to random provocations; they do not take pleasure in the exercise of their faculties for its own sake; ... It is no good speaking to such folk: they cannot be idle, their nature is not generous enough. (Chapter II, paragraph 9)

The commercial spirit was not new to Britain but the eagerness for wealth intensified in the nineteenth century (Houghton, 1957). This fervour was closely linked to the drive for social status. Beatrice Webb (cited in Houghton, 1957, p. 188), daughter of a railroad magnate, described the mid-Victorian creed of social advancement.

It was the bounden duty of every citizen to better his social status ... Only by this persistent pursuit by each individual of his own and his family's interests would the highest level of civilisation be attained.

In $19^{\text {th }}$ century Australia the transition to time-thrift was assisted by a campaign for an eight hour work day which created a model for the mid-Victorian concept of social advancement. By midcentury there was great hope among working-class Australian men that the increased leisure opportunities resulting from the successful campaign for "Eight hours labour, eight hours recreation, eight hours rest" (Clark, 1978, pp. 93-4) would provide the opportunity to become healthy, wealthy and wise. Trade unions in New South Wales and Victoria had successfully contested longer working hours to create more leisure time for workers and the rational recreation movement sought to ensure those leisure hours would be used productively. The rational recreation movement also emanated from Victorian Britain (Bailey, 1978).

\section{RATIONAL RECREATION}

The rational recreation movement sought to uplift the working class by replacing the popular leisure culture "with its emphasis on alcohol, on spontaneity, on emotional involvement, on physical contact [with] ordered, disciplined, improving, educational leisure" (Cunningham, 1980, 
Foley, C. T. (2015). The art of wasting time: sociability, friendship, community and holidays. Leisure Studies. doi: $10.1080 / 02614367.2015 .1055296$

p. 91). Such sentiments were embodied in the philosophy behind the Mechanics Institutes (Lynch \& Veal, 1996, p. 66), first developed in Hobart in 1827, Sydney in 1833, Newcastle in 1835, Adelaide in 1838 and Melbourne in 1839 (Waterhouse, 1995, p. 100), to provide men with self-improving recreation options.

Public libraries emerged in the same era with a similar agenda. While laying the foundation stone for the Melbourne Public Library, the Governor of Victoria offered the following encouragement: "Here you working men will find comfort and society. You will find refuge here, you who frequent public-houses and indulge in strong drinks, a refuge where you will meet a better society" (Hotham, 1854 as cited in Crowley, 1980, p. 323). Rational recreation was sold as a ticket to middle class respectability.

Despite resistance by some women (Burstyn, 1980; Foley, 2005b), these new institutions of rational recreation were established primarily for men. Women were encouraged to aspire to middle class respectability via consumption. Time was devoted to activities such as shopping for fashionable clothing and household goods for the purpose of adorning and beautifying themselves and their homes (Cannon, 1983; Foley, 2005a; Slater, 1997). The cult of domesticity was instrumental in shaping and defining the emerging middle classes (Skeggs, 1997). As middle-class identities materialised working-class identities were vilified: "the working-class were defined by exclusion, as the constitutive limit to the proper person" (Skeggs, 2011, p. 497). Leisure occasions became opportunities to display middle class respectability in the guise of elaborately decorated drawing rooms, fashionable clothing, carriages and other commodities (Foley, 2005a; Foley, 2001). The display of respectability became a signifier of not being working class, and for the aspiring middle classes of the nineteenth century, being defined as working class had become something to fear (Skeggs, 1997).

By the end of the nineteenth century the creed of social advancement (Houghton, 1957) and the quest for middle class respectability (Skeggs, 1997) had taken a firm hold in Australia (Foley, 2001; Veal, Darcy \& Lynch, 2013; Waterhouse, 1995). Australian men and women had internalised the new time sense which brings with it a "restless urgency" to consume time purposively (Thompson, 1967, p. 39). 
Foley, C. T. (2015). The art of wasting time: sociability, friendship, community and holidays. Leisure Studies. doi: $10.1080 / 02614367.2015 .1055296$

By the mid-twentieth century it was noted in both the United States of America (de Grazia, 1994) and the United Kingdom (Thompson, 1967) that time-thrift was well entrenched; time was used purposively `at work and at leisure. Thompson (1967) noted that the pre-occupation with using time purposively had damaged our capacity to employ "the arts of living... how to fill the interstices of [our] days with enriched, more leisurely, personal and social relations" (p. 95). de Grazia (1962) noted that American workers had lost the ability to stop using time purposively, even for short periods, and had lost sight of the notion of leisure as a "state of being in which activity is performed for its own sake" (p. 15); he believed that if the activity is done for a purpose then it is not leisure. In the 1930s, British philosopher, Bertrand Russell (p. 24), argued that "men would not know how to fill their days" (p. 24) if they had more leisure; and added that:

[i]n so far as this is true in the modern world, it is a condemnation of our civilization; it would not have been true at any earlier period. There was formerly a capacity for light-heartedness and play which has been to some extent inhibited by the cult of efficiency. The modern man thinks that everything ought to be done for the sake of something else, and never for its own sake. (p. 24)

The rational recreation movement encouraged individuals to use their leisure time thriftily in self-improving activity (Bailey, 1978). The consequent preoccupation with social status and its commodified symbols may have marred opportunities for sociability (Simmel, 1964). According to Simmel (1964), experiences of sociability are necessarily distanced from the commodity sphere and occur between "individuals who have no other desire than to create wholly pure interaction with others which is not disbalanced by a stress on anything material” (p. 48). In recent decades the emergence of highly social forms of web-based social media has facilitated sociability across time and space. However, the focus on self-interest and self-improvement emanating from the Victorian era appears to have contributed to the increase in narcissism and breakdown in authentic, interpersonal relationships (McDonald et al., 2008), the rise of individualism in the context of an increasingly narrow pursuit of self-interest "that undermines the fabric of civic life and devolves into materialistic selfishness" (Albrecht, 2012, p. 2), and the loss of communal leisure and sense of community (Aria \& Pedlar, 2003; Putnam, 2000; Rojek, 2005) that have been documented in the contemporary era. 


\section{CONTEMPORARY CONSUMERS}

Much of what we busy ourselves with in contemporary Australian day to day life: fitness activity, travel, study, lessons in art, sport and music - particularly for our children (Harrington, 2014), shopping for cosmetic products, designer clothing and fashionable household goods, has roots in the ethic of time-thrift, rational recreation and the creed of social advancement. Consciously or unconsciously, we are socialised to use our time productively in the project of selfhood. McDonald et al. (2008, p. 490) explain: "In contemporary society, self-identity has become a 'project' that is constituted via a process of reflexive self-ordering (Giddens, 1991). Neo-liberal society and its institutions of work and commodified leisure form the basis from which self-identity is informed". We endeavour to use our time (including our leisure time) productively to improve, promote and sell ourselves. If we are idle during periods of leisure, we feel guilty for wasting time.

Contemporary studies of consumer culture in Europe and North America (Chao \& Schor, 1998; Schor 1998; Schor, 2007) tell a similar story. Schor (1998) and Chao \& Schor (1998) document the insidious cycle of work and spend which has emerged in response to increasing concern with competing for social status, a perceived lack of employment security and a fear of falling. In Schor's (2007) view consumption is inextricably tied to the need to achieve and demonstrate social status. As the lifestyles and consumption patterns of the most affluent escalate, many others feel the need to meet a similar standard, regardless of their financial ability to do so. Increased consumption for most means it is necessary to increase work hours. Indeed, Sullivan \& Gershuny (2004) document the plight of middle and high income earners in liberal economies who purchase expensive leisure items but have no time to use them.

In a Swedish context Ehn \& Löfgren (2010) report that for "people who equate losing time with inefficiency, the notion of free time, of simply letting the days pass, is uncomfortable. These people consider an active life to be morally superior, the tradition of being busy to be a necessary part of the moral fabric" (p. 6). 
Foley, C. T. (2015). The art of wasting time: sociability, friendship, community and holidays. Leisure Studies. doi: $10.1080 / 02614367.2015 .1055296$

Some are choosing to opt out of the fast paced lifestyles described by Schor (1998) and slow tourism is among the array of alternatives currently on offer. Slow tourism, it is argued, allows one the opportunity to decelerate the pace of daily life and practice time and space in ways more conducive to personal satisfaction and wellbeing (Parkins \& Craig, 2009). This suggests that slow tourism may provide the ideal conditions for developing friendships and a sense of community. However, there appears to be a certain status attached to niche forms of tourism such as slow tourism. Like eco-tourism before it, slow tourism is being marketed, packaged and sold to the discerning tourist. The slow tourist is encouraged to disparage mainstream tourism as noted in the following website travel tip: "Enter slow travel, where the 'all-in-one' notion is frowned upon and deeper discovery is often earned by merit of your own two feet" (Flight Centre, 2014).

Slow tourism is marketed with magazines, websites, experiences and products as a form of competitive consumption (Fullagar et al., 2012; Schor, 1998); and competitive and status-seeking behaviour is not conducive to forming friendships or establishing a sense of community. Arai and Pedlar (2003) explain:

Where social relations have become driven by competition, contracts and selfinterest, the nature of trust and intimacy is compromised. As Brueggemann (2002, p. 118) describes, 'the fundamental premises on which North American society is based mitigate against the capacity of society to provide for a full social existence of intimate, close connections with others. While possessive individualism and ruthless self-interest provide us with freedom and opportunity, they leave little space beyond the self by which we can obtain social nurture' (p. 187).

Despite initiatives such as the slow movement that provide opportunities to take time out from the fast-paced treadmill of production, consumption and the project of selfhood that comprise the contemporary way of being, we continue to devote little time and energy to the time-wasting activity of establishing "wholly pure" (Simmel, 1964, p. 48) authentic social relationships with the people around us. Perhaps, as de Grazia suggests, those who live in contemporary western societies are no longer capable of experiencing leisure as a 
Foley, C. T. (2015). The art of wasting time: sociability, friendship, community and holidays. Leisure Studies. doi: 10.1080/02614367.2015.1055296

calm and contemplative state of being. Even those of us who study leisure seem to be as removed from the possibilities of experiencing it as the next person.

In contrast, the evidence collected from repeat visitors to caravan parks who were interviewed for this study suggests that these people have temporarily let go of the need for purposive activity linked to achieving and demonstrating status and appear to be adept at enriching their lives with leisurely, personal and social relations over the period of their caravan park holiday.

\section{METHODOLOGY}

The study sought to examine the experiences of repeat visitors to caravan parks - tourists who return to the same caravan park for their holiday, year after year. The aim of the study was to determine what drove these tourists to invest significant amounts of money and annual leave into these annual holidays.

\section{The caravan parks}

Caravan parks in Australia are generally small businesses run by private operators and, at times, by local authorities. Typically they have a mix of caravan and camping sites and self-contained accommodation such as cabins available for hire (Brooker \& Joppe, 2014). Many parks feature attractive facilities such as swimming pools, mini golf courses and tennis courts. While caravan parks have traditionally offered a holiday alternative for lower income families, the rising costs for camping and accommodation over the past decade has impacted upon this 'traditional' group and the market appears to have shifted toward middle income families (Foley \& Hayllar, 2007).

The first group interviewed were enjoying a holiday, typically of around four weeks' duration, at a caravan park on the south coast of New South Wales. These interviews took place onsite during summer school holidays. The second group were interviewed at a caravan park in far north Queensland. Many of the visitors in this second group spend up to three months at that location each year - escaping the winter of the southern states of Australia. The states of New South Wales and Queensland, located on the east coast of Australia, have the highest number of visitor nights spent in the caravan and camping sector (Tourism Research Australia, 2012). Domestic visitors dominate this sector (Tourism Research Australia, 2012; Caldicott \& Scherrer, 
Foley, C. T. (2015). The art of wasting time: sociability, friendship, community and holidays. Leisure Studies. doi: $10.1080 / 02614367.2015 .1055296$

2013). The majority of visitors at both of the parks bring their own caravan or tent with them to the park and hire a site (which can be powered or unpowered). The caravans and tents are set up on the sites and are in close proximity to each other. Camping chairs are inevitably set up outside the tents and caravans. Cabins can be hired and range from a basic room with beds, bathroom, limited cooking facilities and a small veranda, through to luxury air-conditioned condos with king beds, spa baths, full kitchen facilities and entertaining decks.

The New South Wales caravan park is situated at the mouth of a river that provides patrons with direct access to the water. Boat launching ramps, swimming areas on the lagoon and the nearby beaches provide substantial opportunities for water-based recreation including swimming, enclosed water and deep-sea fishing, diving and surfing. The park's locality also provides easy access to national parks, state forests and smaller towns and villages in the coastal hinterland. In addition to these natural attributes, the caravan park is adjacent to a commercial area containing a range of tourist related services and infrastructure including local fast food outlets, restaurants and cafes, a small cinema, a bowling and returned servicemen's club, and a supermarket. At peak periods, typically during the school holidays, up to seven hundred and fifty people will reside in the park. While the management has changed many times, the site itself has been used for camping holidays for more than 80 years. Indeed, one of the participants in the study has been visiting the park for that length of time. The park has evolved from a local government-controlled camping ground to a modern resort-style establishment with a mixture of camping and caravan sites, cabins and condos, a recreation hall, swimming pool and programmed children's activities. No Wi-Fi was available at this park. Peak season for this park is the southern hemisphere summer, particularly the December-January school holiday period.

The Queensland park is somewhat larger, holding more than one thousand visitors during peak holiday periods. It has been in operation under the same manager since the mid1980s. It is a modern resort-style establishment with three swimming pools, tennis court, mini golf course, adventure playground for toddlers to teens, pool tables, bicycle paths, basketball court and outdoor movie facilities. Wi-Fi was available in some sections of the park. A series of free social events are provided by the park management each week including pancake breakfasts, outdoor movies, dance performances, fitness classes and 
bocce games. This park is located on the fringes of an international tourist destination city. The park's locality provides easy access to tourist activities including reef and rainforest tours, markets, beaches and day trips to tropical islands. Peak season for this tropical park is the southern hemisphere 'winter', referred to as the dry season, where maximum daily temperatures remain fairly constant at a comfortable 25 degrees Celsius.

During peak seasons the fees for staying at the parks ranged from around 400AUD per week for a tent site up to 4000AUD per week for a cabin. Cheaper accommodation is available in each of the destinations in which the parks were located in the form of holiday units and motel accommodation.

\section{Data collection}

In order to explore the experience of the caravan park holiday with repeat visitors the researchers sought to elicit rich information in the form of stories, descriptions and personal analysis from the informants. For the purposes of the study repeat visitors were deemed to be those who had been returning for an annual holiday for a minimum of five years. The primary technique for data collection employed in this study was the in-depth interview.

The purpose of the interviews was to identify the 'attraction' of a caravan park holiday that kept people coming back to the same holiday park year after year. To this extent, the interview process was open-ended. However, given the objective of the study, the overall framework sought responses to the following general themes:

- personal histories of caravanning and camping and memories of these earlier experiences;

- benefits derived from the contemporary experience, the reasons they return to the same location on a sustained basis; and

- impact of the holiday on relationships with family and fellow tourists.

One researcher stayed on-site for the duration of the interviewing periods. Participant observation was not designated as a data collection technique; however, one researcher made brief field notes of observations made during the interview periods. The managers of the caravan parks assisted with access, introducing the researchers and the purpose of the study to the 
Foley, C. T. (2015). The art of wasting time: sociability, friendship, community and holidays. Leisure Studies. doi: 10.1080/02614367.2015.1055296

participants. Interviews were conducted with 67 repeat visitors. The interviews were audiorecorded with the informed consent of all participants. Care was taken to conduct the interviews at a time and place convenient to the participant. Interviews took place in or around the caravans, tents and cabins of the participants and in some cases in common areas such as playgrounds and laundries. Some preferred to be interviewed alone and others were more comfortable being interviewed in the presence of a friend or family member. The length of the interviews varied from 10 minutes through to one and a half hours. The first two interviews were conducted by two researchers. All other interviews were conducted by a single researcher.

Two of the participants were holidaying alone and the remainder were accompanied by family members (in most cases spouse, or spouse and children). The participants varied in age from 30 years through to 82 years. Approximately half the participants were aged less than 50 years. The split between male and female participants was almost even. The majority of participants were employed in areas such as retail, trades, agriculture and public service positions (including teachers and police officers). Other jobs included architects (2 participants) and religious ministers (2 participants). About one quarter of participants were retired at the time of the interviews. There were no conspicuous signs of high wealth. Caravans and camping equipment appeared to be mid-range rather than high-end models. Some of the campers had boats with them that they used for recreational fishing. The overall sense of the researcher was that the participants could be described as belonging to middle-income households.

\section{Analysis}

Following the interviews, each of the recordings was transcribed. Codes and themes were generated manually, initially from the interview data and then from the emerging conceptual framework. Data in the form of quotes and field notes were analysed, classified and coded. Two researchers analysed all of the transcribed data independently. There was general agreement between the researchers in terms of the nature of the emerging themes and minimal variation in the classification and coding of data in relation to the themes. Differences were discussed and resolved. 
Foley, C. T. (2015). The art of wasting time: sociability, friendship, community and holidays. Leisure Studies. doi:

The first level of analysis was thematic and shaped by the interview data. The most significant themes to emerge from the data were relaxation, sense of community and friendship. The researchers judged that the views expressed in relation to these themes were strong and pervasive. Further related themes included time, spontaneity, trust, sense of belonging and reciprocity. Given the strength of the response in this regard, the next level of analysis turned toward the literature and an exploration of the notions of community (McMillan, 1996) and friendship (Lynch, 2005; Simmel, 1964) in the context of Thompson's (1967) history of time sense. This exploration arose in a grounded way from the narrative of participants in the study who reported that friendships and a sense of community were special and attractive features of caravan park holidays; these were features they believed to be missing in other types of holidays.

Thematic analysis inevitably involves data reduction.

Data reduction is ... part of analysis. The researcher's decisions - which data chunks to code and which to pull out, which evolving story to tell - are all analytic choices. Data reduction ... sharpens, sorts, focuses, discards, and organizes data in such a way that 'final' conclusions can be drawn and verified. (Miles \& Huberman, 1994, p. 11)

The thematic construct filters the data. In this case it involved discarding data irrelevant to the chosen themes, disconnecting the data by separating, categorising and coding individual pieces of data, and reconstructing the data sets according to a refined and revised set of ideas generated by the analysis of the data in light of the information gathered from the literature (Adams, Khan, Raeside \& White, 2007; Veal \& Darcy, 2014).

In the following discussion pseudonyms have been used to protect the privacy of participants.

\section{RESULTS AND DISCUSSION}

The key themes to emerge from the analysis included the letting go of time-thrift and purposive leisure, the art of friendship and sociable relations, and sense of community. Each of these themes is explored below in a literature based interpretation.

\section{Letting go of time-thrift and purposive leisure}


Foley, C. T. (2015). The art of wasting time: sociability, friendship, community and holidays. Leisure Studies. doi:

The word 'relaxation' was used by most participants to describe their holiday experience. Further prompting elicited many examples (including the following) of the relationship between relaxation and letting go of the need to be doing things.

Relaxing, happy times ... that's what makes you want to come back. ... Once you're here for 4 weeks you're that relaxed you don't have a care in the world to be honest.

[Q: How does that relaxation come about? What contributes to that?]

Sleep, a lot of that. I think it's not having a commitment to anyone, bar your family. There's no work pressures, nothing. You get up, you get out [of the tent], and you've got nothing scheduled to do. I might go for a surf but if I don't, no big deal. You might have breakfast, after breakfast you do lunch and next thing dinner's come along and you've done nothing. You don't worry about it because tomorrow comes and you go surfing and you go fishing and yes, there's no commitment side I suppose. (Matthew)

Matthew's comment draws on another point that was made by many participants - during the period of the caravan park holiday they let go of clock time (linear, finite and not to be wasted) and revert to an older sense of time (cyclical). When time is experienced as cyclical rather than linear there is no sense of wasting time: "You don't worry about it because tomorrow comes...".

Thompson (1967) argued that a combination of the puritan work ethic, the industrial revolution, and the introduction of clocks to the wider population brought about a fundamental change in our way of being: a shift in time sense. To illustrate this point he painted a picture of an older way of being when "one-handed clocks sufficiently subdivided the day" (Hardy as cited in Thompson, 1967, p. 56) and people were prone to, "for an hour, or for hours together ... sit on a bench, or lie down on a hillock ... or collect in groups by the roadside, [find] occasions for ... jocularity" (Foster as cited in Thompson, 1967, p. 90). This older, pre-clock sense of time was experienced as cyclical and endless, with the rolling around of day upon day and season upon season. However, Puritanism, in its marriage of convenience with industrial capitalism, converted us to new valuations of time "which taught children even in their infancy to improve each shining hour" (Thompson, 1967, p. 95); consequently, our minds became saturated with a new time 
Foley, C. T. (2015). The art of wasting time: sociability, friendship, community and holidays. Leisure Studies. doi: 10.1080/02614367.2015.1055296

discipline (Thompson 1967). According to Hodgkinson (2005) the "idea that idleness is good goes against everything we have ever been taught. Industry, hard work, duty, self-sacrifice, toil: surely these are the virtues that lead to success in life" (preface)?

John's comment (below) suggests that for some there is a need to adjust to the pre-clock time sense.

Absolute freedom. No timetables. It has taken us a while to get used to that idea. It took a couple of months. You wake up in the morning and think: "What am I going to do today?"

Tim elaborated on the sense of freedom he experienced when letting go of clock time.

Do what you like when you like. No alarm clocks, the sea, all that sort of thing. Things just happen spontaneously, say 'let's have a barbecue, we'll have it at your place, no we'll have it at my place" and so on.

Many participants mentioned the letting go of set meal times as a feature of being in holiday mode. Barry told a story of his irritation when a friend who joined his family for a week tried to instil a sense of clock time into the holiday.

At half past six at night she said "what are you having for tea"? I said "I don't know". "It's half past six!" [said the friend]. I said "yeah this is holidays you don't have to get up for work in the morning". I said "we might have steak we might have fish, might have a sardine sandwich, but you're on holidays so it doesn't really matter". So when you look at that attitude you can enjoy it. If you get all uptight you won't enjoy it.

When asked to describe her caravan park holiday Kelly explained it was ... unplanned so you don't feel like you've got to go here and on Tuesday we 're going there, although tomorrow we plan to go out for breakfast but that's about as far as it goes. ... it's like no program which is really good for us to unwind. 
Foley, C. T. (2015). The art of wasting time: sociability, friendship, community and holidays. Leisure Studies. doi:

She told a story of her discomfort when another family interrupted the spontaneity she cherished:

Some people want holidays to have everything set, they want to tick boxes. There was a family who were friends of friends and they had all these things they'd researched on the internet before they came that they were going to do while they were down in this area and they were just like, doing things everywhere. I couldn't stand it.

Linked to the older sense of time is the letting go of time-thrift and the need for purposive leisure (Thompson, 1967). Beverley, in her sixties and from a farming background, comments upon her freedom to watch videos and tennis (on television) while holidaying at the caravan park activities that she may consider to be time-wasting in other contexts.

We can relax, and I love watching the tennis. I watch a lot of tennis and I watch a lot of videos 'cause I never watch videos at home. I don't think I've ever been to the video shop at home, so it's just a different lifestyle you have here. When you're home you feel you've got to be doing things, you haven't got time to be sitting around watching videos. All right, that's me anyway. Down here I don't feel I owe anybody anything, I'm not responsible for anything.

Along with a number of other participants Beverley reflected on the difference between the experience of the caravan park holiday and other sorts of holidays where she was much more likely to use time purposively - visiting art galleries, museums, natural and built heritage sites and other attractions.

This is still the best way to have a holiday. This is what we call our holiday. The others are trips, you're going places to see things. We've seen things we wanted to see, well not everything, there's always something new to see if you want to, but we're not seeking to find new things when we come here. (Beverley)

These comments indicate that the respondents revert to an older way of being when they visit the caravan park for their annual holiday. They are not ruled by the clock and they consciously let go of the "restless urgency to consume time purposively" (Thompson, 1967, p. 39). 
de Grazia (1962) draws on the ancient Greek ideal of leisure to highlight what has been lost to western societies since the impact of the industrial revolution. Leisure in the classical sense, according to de Grazia, is not an activity, nor a period of time free from work obligations, but a state of being, free from the necessity to labour. It requires that we stop watching the clock, drop our stressful and busy schedules, sit back, preferably in a rural setting, and contemplate. According to Louise, whilst on this holiday, she and her husband "don't have to move, don't have to go anywhere, just sit still. For our family in particular that's really good because we're [usually] really busy".

These comments suggest connections between the experiences of the caravan park tourists and the concept of slow tourism. Links with letting go of time-thrift and slow tourism are apparent in so far as for the period of their holiday the participants in this study have stepped "off the treadmill” (Fullagar et al., 2012, p. 1). But slowing down or even sitting still (as described in the quote above from 'Louise') may be just part of what is needed to provide the right environment for the development of friendship and community. The evidence above suggests that it is also important to let go of the need to be engaged in purposive and self-improving activity. This may have implications for the slow tourism movement with its focus on activities associated with environmental sustainability (Hall, 2012; Lipman \& Murphy, 2012), pilgrimage (Howard, 2012), and even health and personal development (Fullagar et al., 2012). Oh et al. (2014) report that slow tourism tends to be "goal-driven activity or series of activities, as in a trip down the Amazon, an archaeological excursion, or a religious pilgrimage all having experiential goals of one sort or another" (p. 2). The literature on slow tourism makes reference to enhanced relationships and conviviality (Fullagar, 2012), particularly in the context of hosts and guests (Wearing et al., 2012). However, slow tourism undertaken for utilitarian purposes may be perceived as another cog in the wheel of social advancement which, in the end, may not be conducive to leisurely sociable relations.

\section{The art of friendship and sociable relations}

My boys do swimming [at a local pool in their home suburb], I see the same parents when I drop them off [each week] but I'd only have a 2-3 minute conversation, 
Foley, C. T. (2015). The art of wasting time: sociability, friendship, community and holidays. Leisure Studies. doi:

maximum, with any of them. I've made better friends in two days at a caravan park, which is kind of sad. I heard someone say we're not human 'beings' any more, we're human 'doings'. And I agree. This place [the caravan park] helps you connect. (Alice)

This insightful comment from Alice (a young mother holidaying at the Queensland park with her children) reinforces de Grazia's (1962) point that leisure is a state of being and not about doing things and Thompson's (1967) argument that too much doing is not conducive to developing leisurely, sociable relationships. The majority of participants in this study referred to friendships and/or family relationships and a sense of community in the context of the caravan park holiday. Terry commented that he'd been "coming here for 12 years and have probably got some of the best mates here. Yep, I talk to locals as well as people that camp in the park [and] apart from family [they are] some of the closest people to me". Barry echoed these sentiments and those of his wife for whom their holiday was about “friendship. 100 per cent friendship. I believe once you've made a friend you've always got a friend and this is what it's all about, coming, the friendships".

A number of the participants expressed a belief that a caravan park style of holiday is conducive to the spirit of friendship because of the friendly atmosphere. Friendship in this holiday context may be easier because it avoids some of the fragmentation and differentiation that affects friendship within the context of everyday life (Lynch, 2005). Simmel (1964) argued that modern culture, society and personality are by nature fragmented:

[T] he modern ways of feeling tends more heavily toward differentiated friendships, which cover only one aspect of the personality, without playing into others aspects of it...These differentiated friendships which connect us with one individual in terms of affection, with another, in terms of common intellectual aspects, with a third, in terms of religious impulses, and with a fourth, in terms of common experiences - all these friendships present a very peculiar synthesis in regard to the questions of discretion, of reciprocal revelation and concealment. They require that the friends do not look into those mutual spheres of interest and feeling which, after all, are not included in the 
Foley, C. T. (2015). The art of wasting time: sociability, friendship, community and holidays. Leisure Studies. doi:

relation and which if touched upon, would make them feel painfully the limits of their mutual understanding. (p. 326)

Differentiated friendship is an outcome of the plurality of claims made upon the individual caught in the intersection of cross-cutting interests and expectations. While this encourages the expression of individuality and a greater differentiation between persons, it makes for a discontinuity in personal relations. As a consequence, Simmel (1964) believed modern individuals may have difficulties sustaining friendships. However, in the relaxed atmosphere of the caravan park the claims made upon individuals appear to be minimal. In this holiday context a community of like-minded people with a great deal in common appears to be created.

You get to know the people around you and that dictates your atmosphere, whether you have a beer at $3 \mathrm{pm}$ and neighbours come over because you're eating prawns or you've got some nibblies on the table. There's no animosity, it's a great atmosphere of togetherness. (Brian)

Someone started a social game of cricket on the grass and within 20 minutes every one of these tents was involved, they were having a drink, fielding from their chairs, about 30-40 people involved across all ages. It was all spontaneous, nobody knocked on tent walls, it was like a carnival. (Tony)

Further to this, participants expressed a sense of faith that other holiday makers at the caravan park would be interested in their friendship. Leanne comments that:

[t]he people who intend to camp and who are prepared to live close to each other are friendly. You're outside cooking and eating and you don't have a phobia of being close to a whole lot of people. I guess it's not as private as it would be in an [holiday] apartment. [Caravan parks] attract those sorts of people; friendly people who like other people.

The following comment suggests that caravan parks engender a sense of trust in ways that other types of holidays fail to do: 
Foley, C. T. (2015). The art of wasting time: sociability, friendship, community and holidays. Leisure Studies. doi:

If you're in a [holiday] unit you don't know whether [your neighbour] is a banker or plumber or labourer ... There's a lack of trust there ... You think oh no he might just want to be left alone. You've got to shut your door whereas the caravans and the cabins are always open. (Barry)

The participants in this study chose to revisit the caravan park each year for a holiday and one of the main reasons that brought them back year after year was the community of friendship they found there.

You meet people here that you've met all the years. When you come here it's like old home week. You arrive here and walk around and catch up with all the people that you see from year to year and they're all on holidays. (Clare)

For many, the friendship and trust that had developed resulted in a sense of belonging. For Keith, a long term visitor,

I actually used to scoff at people who came back to the same place all the time ... I couldn't understand what the attraction was. But now I do ... It's a community of friendship... It's almost for us now after this many years like a sense of homecoming when you pull in the gate. And that's the part I was saying about its being easy. You don't have to learn the ropes all the time. It's knowing how things go. And it's that sense of homecoming.

Beverley described the pleasure of returning to the caravan park as "kind of like coming home. It's not home but it's kind of like coming home, it's a place you know".

The sense of belonging also extended outside the boundaries of the caravan park into the local community. According to Jean,

people recognise you, the locals you know. The guy at the butchers, soon as you arrive, "Hi, how are you going?" It's like you just saw him yesterday. Sometimes you get a better reception here than at home where you do your shopping every week. 
Foley, C. T. (2015). The art of wasting time: sociability, friendship, community and holidays. Leisure Studies. doi: 10.1080/02614367.2015.1055296

Trust and a sense of belonging are integral to development of friendships (McMillan, 1996). Friendship also appears to be linked to the relaxing social space of the park where the people on holidays are happy to while away the hours chatting to people. In Simmel's (1964) terms, the social space of the park is one where the serious content of the everyday life world falls away and conversations take place with no serious intent. Rather, they are conversations for the sake of conversations - for the sake of communicating sociably with others without ulterior motive or serious purpose. Terry spoke of people walking past his tent and stopping to say hello, sometimes having coffee. He told a story of setting off to visit the bathroom in the amenities block and getting "back two hours later, people grab you on the way". Friendships were important to Beverley's experience of the caravan park.

[Beverley and her husband] don't come with anyone but we're very busy from the time we get here. We have lovely people behind us and beside us. We love the lifestyle. We come here for four months but if we took a [holiday] unit we wouldn't see anyone. As much as we love each other's company we love being able to talk to the world, and you do. It's the friendliness ... Three weeks ago a little boy went past and called out 'Bev, Bev'. It was a little boy who was here last year.

John contrasted the friendliness of the caravan park environment with the more reserved environment of his high-rise apartment at home.

It's a way of life... because of the people. The people I meet in caravan parks are either of my age group or young families, a mixture of people. They've all got time on their hands and are fairly relaxed. It's friendly, you meet people by walking up the road ... You get to meet your neighbours if you want to. Sometimes you exchange pleasantries and that's all, sometimes you click with a couple and you end up having morning tea together, or lunch, or dinner, and you end up exchanging Christmas cards. Particularly for me it's friendly because I live on my own in a high-rise apartment, a vertical community, but not one where you get to know people too well. 
Foley, C. T. (2015). The art of wasting time: sociability, friendship, community and holidays. Leisure Studies. doi:

Caravanners or campers have got the world at their feet, they're looking for the same type of thing; that's why it's so easy to make friends. I can't explain it beyond the word atmosphere.

There is a difference between friendliness and friendship in terms of the depth of concern and interaction (Lynch, 2005). It may be that the general friendliness that pervades the caravan parks provides the context for the development of more genuine friendships.

Georgia commented on the relationships that develop within and between families in caravan parks.

When you get here your own life stops for a small period of time and you get to enjoy a combined family life. Not just your family but other families that you would connect with. There's a real camaraderie.

In some cases friendships were confined to the social space of the caravan park holiday and reaffirmed each year. In others, friendships extended beyond the boundaries of the caravan park holiday.

The people next door are always on the same site, we're always on the same site. We don't have any contact through the year with them but it's nice to see them here. (Kayla)

In the seven years we've been coming here we've created so many friends, they extend beyond the three weeks we spend here. (Beatrice)

Lynch (2005) argues that friendship is a voluntary relationship involving an emotional bond, and that the emotional attachment between friends is a reciprocal one. McMillan (1996) contends that friendship generates trust, reciprocity and a sense of belonging. Numerous authors concur that friendship does not succeed when there are attempts to use others for gain (Lynch, 2005; McDonald et al, 2008; Simmel, 1964). Genuine friendship, it seems, is focussed on interaction for its own sake. There is a shared agenda between such friends but it has no particular purpose or instrumental purpose (Lynch, 2005). The many stories of sharing and caring for each other 
Foley, C. T. (2015). The art of wasting time: sociability, friendship, community and holidays. Leisure Studies. doi: 10.1080/02614367.2015.1055296

that were related during the interviews provide evidence that friendships bring benefits. But the evidence also suggests that these friendships evolved precisely because those involved have not had any ulterior motive in their generosity. Perhaps letting go of purposive activity and the need to be doing things also allows us to let go of the need to use others for gain (Lynch, 2005, McDonald et al., 2008).

\section{Sense of community}

The spirit of friendship is an essential ingredient in the development of a sense of community among any social group (McMillan, 1996). The vast majority of participants made reference to the sense of community that exists among the caravan park visitors for the duration of their holiday each year.

The sense of community in the caravan park is second to none. (Kelly)

It is a community, everyone coming back each year makes it that way, like a country town atmosphere. (Beatrice)

It's friendly, relaxed, co-operative - everyone helps each other. It's a community with lots of community meals and all that sort of thing. It's really good. (Terence)

It's just the community atmosphere, and the kids, when they were little, they always had someone to play with. A community game of cricket, or fishing, or golfing, and we'd often go to the beach and we'd take kids from 4 or 5 different families, that was really good too. (John)

In addition to the stories of friendship, trust and a sense of belonging discussed earlier in the paper, the participants expressed a sense of mutual care and responsibility for each other. There were many stories told of people looking after each other in the face of adverse weather conditions.

The other day a big nor'easter blew up and blew some tarps off. All of a sudden people were helping each other without thinking about it because it might be your turn next. (Gabriel) 
Foley, C. T. (2015). The art of wasting time: sociability, friendship, community and holidays. Leisure Studies. doi:

It's a culture I never thought I would have been into but I just love it. There are so many interesting people you meet on the road-old people, young families. You go out, it's raining, come back and someone's taken the washing off the line for you and folded it. (Kate)

And they look out for you and it's nice to know if something goes wrong with the car or whatever, everyone pitches in to help out or if someone gets flooded out everyone goes to help with drying out their bedding. So that kind of sense of community. If we catch heaps of fish we give it away. That's the kind of community thing that builds up. (Helen)

There were a number of references to the communal care of children.

Ifeel safe with the kids here. It may be a false sense of security but I think while I'm here I've never had any trouble. You feel safe; we've been coming here a long time. People in the park all know the kids and where they should belong and if something happened someone will come and say "I saw your kids over there, should they be there?". (Matt)

Everyone's always willing to give everyone else a hand, at the boat ramp, putting the tent up. If a kid falls you pick them up. At other places you wouldn't dare touch a child. (Noel)

Michael was away from the caravan park site when his son, Tim, broke his arm. His wife Denise went:

to the next door neighbour who took Tim and Denise to the ambulance - the ambulance took them to Moruya. By the time I came back they've gone to Moruya, worked out they can't fix his arm there so they've gone to Bega. On the way past I've come back and told everyone what's happened, and I kept on following the ambulance. After we come back the whole thing was all packed up 'cause I knew I was going the next day, so everyone's come, packed up all our clothes, pulled everything apart, dropped the tent and packed it all into the trailer. They didn't 
Foley, C. T. (2015). The art of wasting time: sociability, friendship, community and holidays. Leisure Studies. doi:

have to do that - I just said 'yep we'll be going tomorrow, I'll have to come back tonight and start packing up'. Twenty people did it. They just came, pulled it all apart and packed it up. It happens here. There's a good community of people here. You do look after each other.

McMillan (1996) contends that communities are also shaped by stories of a shared history. However, it is not necessarily a history that each one must have participated in but one whose ideas they embrace as a group. Each year the tourists return to the park and engage with each other. A shared history of their experience in the caravan park emerges from this annual recasting of community engagement. A sense of long-lasting and valued relationships was the theme of many stories.

It's primarily the people that we've met and have remained friends with [that keeps us coming back to this caravan park]. The kids my boys used to play with when they were small are still here, they're still coming. Even if I can only get down here for a week or a weekend they've still got to come here in January. We know people from all over Australia, from Newcastle, from Wollongong, Melbourne, Goulburn - it's one of the key things - we know people from all those areas from this. It's very important to the kids. They get invited to each other's 21sts, weddings and all that sort of stuff. (Ian)

There was more than one mention of couples who met at the caravan park as children and went on to marry.

She was saying she used to come down here when they were children and then she met her husband here and so you hear the stories about ones who have come on holidays, grown, and then their children have come and they've met the ones who live next door, because you see all the young ones get together, and then they come back every year and they become friends, then they become girlfriends and boyfriends. (Nancy)

A poignant story was told of one elderly man's final visit to the caravan park. The theme of this story seemed to be a celebration of a life full of rich holidays at this particular caravan park. 
Foley, C. T. (2015). The art of wasting time: sociability, friendship, community and holidays. Leisure Studies. doi:

When we first arrived there was an old couple in the caravan up the back. He came from The Entrance up near Newcastle to here every year for about 45 years. The last time he come he said "I don't think you'll see me again because the son's coming to drive me back", but he said "I've enjoyed every minute I've ever come here". (Rod)

\section{CONCLUSION}

The puritan value of time-thrift and the related practice of using time purposively have had a significant impact on western lifestyles over the modern period. Time-thrift and the purposive use of time underpinned the success of the industrial revolution and the subsequent development of western economies (Thompson, 1967) and were central to the nineteenth century rational recreation movement (Bailey, 1978). As societies became more secular the puritan drivers of the purposive use of time were supplanted by the drive to consume (McDonald et al., 2008). Timethrift continues to be valued in the time-stressed, contemporary lifestyles of the overworked and the overspent (Schor, 1992; Schor, 1998). We perceive that time is a commodity in short supply and feel guilty if we waste our leisure time on idle pursuits. Rational recreation has evolved into the project of selfhood where we work to construct a self that will sit comfortably in the social class to which we aspire. Leisure has become inextricably linked with aspirational consumption (McDonald et al., 2008; Schor, 1998).

Over the centuries the effects of time thrift and the purposive use of leisure have damaged our capacity to experience the leisurely, social relationships that underpin friendship and community (Arai \& Pedlar, 2003; McDonald et al., 2008; Putnam, 2000; Rojek, 2005; Thompson, 1967). Slow tourism is a potential remedy, with its opportunities for the development of convivial relationships (Fullagar, 2012) and communal well-being (Oh et al., 2014). By its very nature it appears to reject time-thrift. However, as slow tourism itself becomes a source of conspicuous consumption and accumulates the trappings of status, it risks damaging this potential. The findings of this study suggest that friendship and community thrive more readily in conditions where status seeking behaviour is discarded along with time-thrift.

Data drawn from a study of two caravan park holiday communities in Australia suggest that the art of friendship and sociable relations, and a sense of community can be reclaimed through the 
Foley, C. T. (2015). The art of wasting time: sociability, friendship, community and holidays. Leisure Studies. doi: 10.1080/02614367.2015.1055296

relatively straightforward techniques of letting go, even temporarily, of both time-thrift and the compulsion to use leisure time purposively.

In contrast, the regular repeat visitors to two caravan parks on the east coast of Australia appear to be adept at building and maintaining leisurely, personal and social relations. The friendships and sense of community that exist among regular visitors to the two caravan parks appear to be a major source of the parks' attraction and inspire people to return to the same site, at the same time each year, for their annual holiday experience.

For the duration of their caravan park holiday, the participants in this study revert to an older sense of time, let go of the need to engage in purposive leisure, and adopt a more classical approach to leisure - as a state of being rather than activity (de Grazia, 1962). The findings indicate that this set of behaviours and attitudes opens up space for developing and maintaining friendships, building aspects of trust and the mutual benefits that come from being part of a transient yet meaningful community, and contributing to and enjoying the symbolic celebration of these qualities.

There are class-based factors that may have influenced the success of these communities. Firstly, the communities appear to be made up of like-minded people who come from similar socioeconomic backgrounds. Simmel (1949) argued that sociability was more likely to succeed within the boundaries of a single social class. In addition, although caravan parks in Australia are currently catering to a middle income clientele, for many decades they were the holiday choice of working class families (Foley \& Hayllar, 2009). It may be that this history has protected the Australian caravan park holiday from becoming a marker of the successful conspicuous consumer.

This paper explored a set of shared behaviours and attitudes that have allowed friendships and a sense of community to develop and flourish in two holiday park communities. The trick, it seems, is to create spaces where people are comfortable to let go of "the desire to consume time purposively, which most people carry just as they carry a watch on their wrists" (Thompson, 1967, p. 95). The evidence presented in this paper suggests that we have the capacity to develop 
Foley, C. T. (2015). The art of wasting time: sociability, friendship, community and holidays. Leisure Studies. doi: 10.1080/02614367.2015.1055296

a leisure ethic that values idleness, free time, sociability and unproductive activity. Over time, we may relearn the art of wasting time.

\section{References}

Albrecht, J.M. (2012). Reconstructing individualism: a pragmatic tradition from Emerson to Ellison. New York: Fordham University Press.

Arai, S. \& Pedlar, A. (2003). Moving beyond individualism in leisure theory: A critical analysis of concepts of community and social engagement. Leisure Studies, 22 (3), 185-202.

Aristotle, (1985). Nicomachean Ethics. In J. Barnes (Ed.) The Complete Works of Aristotle. Princeton: Princeton University Press.

Bailey, P. (1978). Leisure and class in Victorian England. London: Routledge Kegan Paul.

Brooker, E. \& Joppe, M. (2014). A critical review of camping research and direction for future studies. Journal of Vacation Marketing, 20(4), 335-351.

Burstyn, J. (1980). Victorian Education and the Ideal of Womanhood. London: Croom Helm.

Caldicott, R. and Scherrer, P. (2013). Facing divergent supply and demand trajectories in Australian caravanning: Learnings from the evolution of caravan park site-mix options in Tweed Shire. Journal of Vacation Marketing, 19(2), 117-131.

Cannon, M. (1983). Australia: a history in photographs. South Australia: Currey O’Neil.

Chao, A. \& Schor, J. (1998) Empirical tests of status consumption: Evidence from women's cosmetics. Journal of Economic Psychology, 19, 107-131.

Clark, C. M. H. (1978). A history of Australia IV: The earth abideth forever, 1851-1888. Melbourne: Melbourne University Press.

Crowley, F. (1980). A documentary history of Australia volume I1: Colonial Australia 17411874. West Melbourne: Nelson. 
Foley, C. T. (2015). The art of wasting time: sociability, friendship, community and holidays. Leisure Studies. doi: 10.1080/02614367.2015.1055296

Cuningham, H. (1980). Leisure in the industrial revolution. London: Croom Helm..

de Grazia, S. (1962). Of time, work and leisure. New York: Kraus.

Ehn, B. and Löfgren, O. (2010). The secret world of doing nothing. Berkeley, CA: University of California Press.

Flight Centre (2014) Travel tips. Retrieved from http://www.flightcentre.com.au/travel-news/traveltips/exactly-slow-travel-movement/)

Foley, C.T. (2001). Revellers, ornaments and angels: British and colonial origins of women's leisure in Australia. Unpublished doctoral dissertation. University of Technology, Sydney.

Foley, C.T. (2005a). Women's leisure? What leisure? Has it always been this way? Annals of Leisure Research 8(4), 207-227.

Foley, C.T. (2005b). Subversive possibilities: An exploration of women's leisure resistance using historical case studies. Annals of Leisure Research 8(4), 228-249.

Foley, C.T. and Hayllar, B. (2007). A tale of two caravan parks: Friendship, community and the freedom thing. Tourism Today, 7, 7-28.

Foley, C.T. \& Hayllar, B.R. (2009). Freedom to Be: Friendship and community at holiday parks. In S. Fleming (Ed.), Leisure and tourism: International perspectives on cultural practice (pp. 33-52). London: Leisure Studies Association.

Fullagar, S. (2012). Gendered cultures of slow travel: women's cycle touring as an alternative hedonism. In Fullagar, S., Markwell, K. \& Wilson, E. (Eds.) Slow tourism: Experiences and mobilities Bristol: Channel View Publications

Fullagar, S., Markwell, K. \& Wilson, E. (Eds.) (2012). Slow tourism: Experiences and mobilities. Bristol: Channel View Publications. 
Foley, C. T. (2015). The art of wasting time: sociability, friendship, community and holidays. Leisure Studies. doi: 10.1080/02614367.2015.1055296

Hall, C.M. (2012). The contradictions and paradoxes of slow food: environmental change, sustainability and the conservation of taste. In Fullagar, S., Markwell, K. \& Wilson, E. (Eds.) Slow tourism: Experiences and mobilities. Bristol: Channel View Publications.

Harrington, M. (2014). Practices and meanings of purposive family leisure among working- and middle-class families. Leisure Studies, 1-16. DOI: 10.1080/02614367.2014.938767.

Houghton, W.E. (1957). The Victorian frame of mind 1830-1870. London: Oxford University Press.

Hodgkinson, T. (2005). How to be idle. New York: HarperCollins

Howard, C. (2012). Speeding up and slowing down: pilgrimage and slow travel through time. In Fullagar, S., Markwell, K. \& Wilson, E. (Eds.) Slow tourism: Experiences and mobilities Bristol: Channel View Publications.

Lipman, M. B. \& Murphy, L. (2012). 'Make haste slowly': environmental sustainability and willing workers on organic farms. In Fullagar, S., Markwell, K. \& Wilson, E. (Eds.) Slow tourism: Experiences and mobilities Bristol: Channel View Publications.

Lynch, R. \& Veal, A. J. (1996). Australian leisure. Australia: Longman.

Lynch, S. (2005). The philosophy of friendship. Edinburgh: Edinburgh University Press.

McDonald, M., Wearing, S. \& Ponting, J. (2008). Narcissism and neo-liberalism: work, leisure and alienation in an era of consumption. Loisir et Societe (Society and Leisure), 30(1), 489-510.

McMillan, D. (1996). Sense of community. Journal of Community Psychology, 24 (4), 315-325.

Miles, M. \& Huberman, M. (1994). Qualitative data analysis: An expanded sourcebook (2nd ed.). California: Sage.

Oh, H., Assaf, A. \& Baloglu, S. (2014) Motivations and goals of slow tourism. Journal of Travel Research, doi: 10.1177/0047287514546228. 
Foley, C. T. (2015). The art of wasting time: sociability, friendship, community and holidays. Leisure Studies. doi: $10.1080 / 02614367.2015 .1055296$

Putnam, R. (2000). Bowling alone: The collapse and revival of American community. New York: Simon and Schuster.

Rojek, C. (2005). Leisure theory. New York: Palgrave Macmillan.

Russell, B. (1935). In praise of idleness and other essays. London: George Allen \& Unwin.

Schor, J. (1998). The overspent American: Upscaling, downshifting, and the new consumer. New York: Basic Books.

Schor, J (2007). In defense of consumer critique: Revisiting the consumption debates of the twentieth century. The Annals of the American Academy, 611(1), 16-30.

Simmel, G. (1964). Sociability. In Kurt Wolff (ed) The sociology of Georg Simmel. New York: The Free Press.

Skeggs, B. (1997). Formations of class and gender: Becoming respectable, London: Sage.

Skeggs, B. (2011). Imagining personhood differently: Person value and autonomist workingclass value practices. The Sociological Review, 59(3), 496-513.

Slater, D. (1997). Consumer culture and modernity. Cambridge: Polity Press.

Stevenson, R.L. ([1877] 2004). An apology for idlers. In W.L. Phelps (Ed.) Essays of Robert Louis Stevenson. Project Gutenburg. Found at: http://www.gutenberg.org/cache/epub/10761/pg10761.html

Thompson, E.P. (1967). Time, work-discipline and industrial capitalism. Past and Present, 38, 56-97.

Tourism Research Australia (2012). Snapshots 2012 - Caravan or camping in Australia. Canberra: Australian Government.

Veal, A. J., Darcy, S. \& Lynch, R. (2013). Australian leisure $4^{\text {th }}$ edition. Frenchs Forest: Pearson. 
Foley, C. T. (2015). The art of wasting time: sociability, friendship, community and holidays. Leisure Studies. doi: 10.1080/02614367.2015.1055296

Veal, A. J. \& Darcy, S. (2014). Research methods in sport studies and sport management. London: Routledge.

Walton, J.K. (2014). From institution to fragmentation: the making and unmaking of the British weekend. Leisure Studies, 33(2), 202-214, DOI: 10.1080/02614367.2013.855938.

Waterhouse, R. (1995). Private pleasures, public leisure: A history of Australian popular culture since 1788. South Melbourne: Longman.

Wearing, S., Wearing, M. \& McDonald, M. (2012). Slow'n down the town to let nature grow: ecotourism, social justice and sustainability. In Fullagar, S., Markwell, K. \& Wilson, E. (Eds.) Slow Tourism: Experiences and mobilities Bristol: Channel View Publications. 